\title{
The Window Girls Move Past Continually: Thoughts On Photography
}

In 1934 at a public meeting organized by the Belgian Surrealists, Andre Breton delivered a lecture called "What is Surrealism?" In it, he summed up the mission of Surrealism with this sentence: "Our unceasing wish, growing more and more urgent from day to day, has been at all costs to avoid considering a system of thought as a refuge, to pursue our investigations with eyes wide open to their outside consequences and to assure ourselves that the results of these investigations would be capable of facing the breath of the street."

The breath of the street. Such a curious phrase: though it acknowledges that the goal of Surrealism is opposite to any "system of thought," which the Surrealists clearly spurned, it doesn't exactly line up with what we have come to think of as the central Surrealist attraction to unconscious impulses, either. Breton's formulation, in fact, has little to do with how we now use the word-as an exclamation we lob into conversation as a synonym for the unexpected, the strange, the unheimlich. So watching a jet plane crash into a building is "surreal," in our terms, because it doesn't follow system, and drops us, for a time, into an experience that works with the illogic of dreams. Capturing the "breath of the street," on the other hand, is a woolier sort of desire, in which you work to lay a net over the foul blague of the real out there, to map its accidents, fold crap and transitoriness and the uncut corners into art. By this definition Surrealism is the ultimate Modernism: the realism of an atomized and random world.

Photography - the photography of the street, at any rate-is by these terms Surrealism. Consider an old snapshot from fifteen or twenty years ago, the one you still look at sometimes with increasing wonder about your connection to the person you were then, to the body-shape and shake-scene you inhabited, the hair, the skin, the look in the eye, the bones on the back of your hand. I am holding, for example, a photograph of my younger brother that I took in June 1974. I was thirteen and he was eleven, and he is at the bottom of a 
chin-up on the back steps, using the pipe that supported our awning. He is straining a little, and smiling, and the soft grain of the picture and the bright day mirror the slight strain in his smile. In the interstices that knit clothing next to clapboard, and in the little accidents of body language between, I feel a small shiver of anagnorisis, Aristotle's word for the insight tragic characters encounter in themselves when they realize how their actions have converged with their fate.

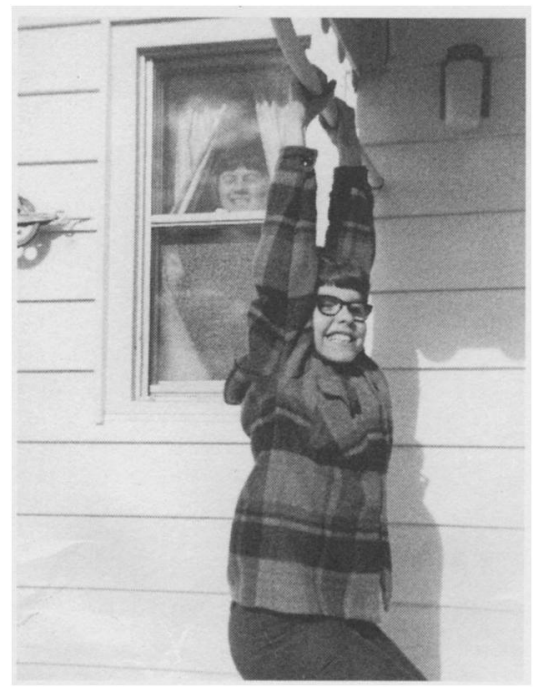

My history is no more tragic than most middle-class lives after, say, Clytemnestra's. But among other things it reminds me that the frame holds a version of the story about me and my brother-my family: the photograph mists into the same grain that holds and clarifies it. Once upon a time we were both there. Now we're not. The silt of the movement between is mesmerizing.

And then something else: My mother's face appears in the little window behind my brother. She has shut her eyes against the bright day, and my brother, hanging from the pipe and believing he is the subject of the photograph, has also squeezed his eyes shut. The visual rhyme is a strange accident, which I like because it leaves them both in the same moment, a little spellbound.

The camera I used to take the pictures was a Christmas present, and when I carried it around with me I knew I was close to an adult form of magic-making. In our not-so-personal Presbyterian world, that was even more personal than my new hockey gloves. By June, hockey was over and I could devote my energy to making art. I snapped photos of my other brother sleeping, our Schnauzer pup chewing socks, my father nodding in a chair in afternoon light, the big maple by the highway just coming into leaf. My brother mowing the lawn, in a corduroy coat. I still have these photos, and some of them have a certain eye for detail or mood. But none has the strange feeling of a "moment" that the chin-up picture has. 
In an essay called "The Photographic Message," collected in Image - Music - Text, Roland Barthes seems to argue something like this. He writes that "the photograph is not simply a product or a channel but also an object endowed with a structural autonomy." Barthes' meaning is obscure, but my sense is that he means a photograph is, accidentally or not, a funny crisscross of simple, dumb "thereness" - a "stencil" of reality, as Susan Sontag put it, "faithful and disappointing" as Philip Larkin wrote-and something random and floating around it that I will call "design," which is what I think Barthes means by "structural autonomy."

This may be like saying that dust is a "version" of architecture, but that is what Barthes (and for that matter Jean-Luc Godard and Claire Denis) often asks his readers to consider in general about words, representations, life, social reality, and so on.

Out of doors I didn't need a flash, an advantage since flash cubes cost extra and I had only a small allowance I earned from mowing the lawn in summer and shoveling snow in winter. I could keep film costs down further by using black and white film, which was fifty cents or so less, and because the guy behind the counter told me, "you can use it to learn with." That made sense to me in an undefined, romantic way. I knew from TV and magazines that black and white meant "art," and I thought about "burning through a few rolls," as I read of enthusiasts doing. But my parents would consider pictures with no people in them a waste of money, so my picturetaking balanced frugality and waste: I wanted urgently to snap away, but I wanted to spend wisely, too.

\section{THE WORLD IS AN ACCIDENT}

Real photographers, especially the generation of the 1950 s and beyond-the geniuses of the snapshot from Helen Levitt to William Klein and Robert Frank and up through Gary Winogrand-were and are, I've since discovered, profligate with film, snapping hundreds of pictures in a day to get two or three negatives that have the cool, spell-binding aura of discovery and accident that I see in the picture of my blindly smiling mother and brother. (When he was taking pictures of New Yorkers in the 1950s, Klein told The New Yorker's Anthony Lane in 2001, that he felt like a "fake anthropologist.") When I was thirteen, squeezing the shutter five times in an after- 
noon was a small death. I'd think that I'd bitten off enough of the world. By comparison, real photographers were gluttons of light and faces, of feet and shadows and strangers, of monkeys in convertibles and bicycles resting, and barber shops, overcoats, cars, babes in arms, crime scenes, crowds shifting like sand, women in shoes, hats, and backgrounds that somehow commented on foregrounds, by the chance of a moment in time.

My snapshot tells me about weather and family, and if I shut my own eyes I can imagine my brother was happy there, happy to be in a picture. It's possible that I was never closer to him than in that pre-adult moment, that spring at the end of grade seven before the turmoil, the very nearly complicated adult glamour, of grade eight, and my vertigo when I was around the budding girls.

And here's the point about my mother: she pushed aside the plastic curtains of the bathroom window to look out just as I was pressing the shutter. It's an accident that she's there-she is un-posedand at the time I was annoyed because she'd spoiled the moment. But afterwards it's clear that the accident of the moment is the picture's subject: her shut, dreaming eyes re-orient the picture and refocus my image of an athlete in training into a literally different frame. I'm sure, given my mother's wicked temper that that's a different frame of mind, too. She is smiling, but in a different way than my brother. She seems caught inside a joy that was rare.

Gary Winogrand famously said that he took pictures of things "to see what they looked like as photographs." He meant that, to some extent, he didn't know why he took pictures of these women's feet, say, rather than some other pedestrians. Something about angle and light and the incidental matter in moving hands and corners of mouths and the fidgets of details-the tricycle behind the child, the barking dog-that you never know about exactly. There's something about an individual moment you can never fully understand, no matter how conscious you are. Your eye, and your inner eye, sharp as they may be, can't see what a study of the frozen artifact gives you the chance to.

And there is accident, which we can now see was the twentieth century's supreme art vehicle: artists turned to the random and to nonsense after World War I, and began to moonland flakes of quotidian matter onto their canvases, their writing paper, their layers of 
nitrate and silver oxide. Not myth, not "experiments" in language, not even consciousness have had the enduring life that accident has.

No form invites the random better than photography. In 1996, a William Klein/Chris Marker exhibit at the Walker Art Center in Minneapolis featured a melancholy audio-loop of Klein, the great American-born, Paris-exiled photographer of wide angles and frame-filling subjects, thinking out a metaphor. Klein's gravelly, French-inflected New York voice seemed to emerge from a REM sleep: "In his life a photographer has, if he's lucky, maybe two or three seconds." Listening, I thought at first he meant the amount of time a street photographer has to factor the light, to focus and fire on a subject who will move or change in another second. But then he clarified: shooting at $1 / 30$ th of a second, $1 / 60$ th, $1 / 250$ th, even the greatest photographer may be able to capture in his lifetime only a couple of seconds of existential human time. And what if he shoots using a motor drive or on video? Klein didn't consider this, but the answer is more or less plain: a photographer could capture more on film, but the place of randomly pointed decision, the play of conscious and unconscious choice, is part of the attraction to the still image. Accumulating images doesn't count as much as the kinked part-seconds when time lines up: light, look, distance, mystery, arrangement, people, and eyes stilling-accident.

Klein's idea is full of an awe that, in philosophical terms, is Greek, and in looking at my photograph I feel the strangeness of accident he describes, that it can improve a plan and add the fifth element. Of what other form of representation can that be said? Architecture requires bales of money, blueprints, meetings to go over the placement of stairwells. Writing rarely escapes multiple drafts before publication. X-rays of great paintings reveal figures re-drawn, deleted, re-situated, painted over, inserted. If there is a place for accident in other arts it is the happy accident of discovering a thing in the long act of making, the better arrangement of a still life, the anecdote from the radio show that feeds the short story. (Frank O'Hara has a great poem on the look of sardines that inspired a friend to begin to paint them. Later, the sardines were painted over but the friend still titled his work, "Sardines.")

It's not hard to add new "elements" to photographs now, and in so doing tamper with the moment. With software like Photoshop, photographers can sit down at their Macintoshes and parachute bodies or 
backgrounds from their existential homes into new ones. With some imaginative cutting and pasting I could be petting a weasel rather than my dog - and so fulfill a terrifying dream I once had. But anyone looking at the photo could also note the difference between the accidental and the deliberate juxtaposition.

\section{ACCIDENT}

Throughout On Photography, a book that almost singularly made photography a legitimate subject for museums and intellectuals, Susan Sontag contemplates a terror of her own: that since 1839 "just about everything has been photographed." Pursuing the overall "meaning" that accrues to the taking of images from the worldfrom Matthew Brady to Diane Arbus-Sontag's subject is truth, lies and the riddling matter between them, beginning with her ominous kick-off voiceover: "Humankind lingers unregenerately in Plato's cave." She is referring to the philosopher's trope of narrowed human vision, the argument that our senses carry us as near to the Real world as shadows to sunlight. Her tone, however, echoes the petulant Puritans that Arthur Miller described in The Crucible. Sontag, normally tough-minded, shows a moral perturbation about the average photographer's aggression. It goes without saying that taking a photograph in public requires more aggression than it does for a writer to make a silent observation. But Sontag's worrying prose implies-more than implies-that the drive to get faces and bodies with the net of a good lens is the tool of the devil.

Her book arose from thinking, she writes, about the "problems, aesthetic and moral, posed by the omnipresence of photographed images," and she concludes that photography has gradually abducted us to the Underworld, as Pluto did Persephone. Pursuing images, she is saying, we turn from direct sunlight back ("unregenerately") to the cave. So she issues Chandlerized policier epigrams- "photographs furnish evidence"-and alarming ideograms about the testicular zeitgeist: "photography has become almost as widely practiced an amusement as sex and dancing .... It is mainly a social rite, a defense against anxiety, and a tool of power."

Sex and dancing? A "tool of power"?

A couple of decades later it is true that an artist like Natacha Merritt can mix voyeurism with a photo diary about her sex life, first on the Internet and then in a book published by Taschen. But a 
graphic mix of body parts and arm's-length angles (Merritt usually photographs herself) is not what Sontag was imagining, and in any event what On Photography circumnavigates for two hundred pages is the core content of the photograph and why it can be so satisfying to look at, and so absorbing, and so delicious. The best photographs are forms of dream, archives of our extreme states. A photograph that gets skin right, under this or that light, can prompt a kind of ecstatic response, a recognition of belonging. When Sabastiao Salgado brings a boiling crowd of travelers, immigrants, migrants into his frame it can be extraordinary: Hieronymous Bosch meets Dorothea Lange.

An intuitive and brave photographer like Sally Mann uses the large negatives produced by her view camera to capture the skin of her slightly wild-looking children - to say that this is the way my family looks now, and this is the way we look, now, two years later; this is my beautiful daughter in a Platonic black-and-white state where her beauty is forever young, but not really, because I know the difference between this picture and my actual daughter. She works to see "family" as a product of imagination and desire, and the figures in the pictures, while they are her kin are also, momentarily, mythic. They are naked but still not known, not least to their mother.

The picture is a grabbed fragment, even when it is posed, family in front of house. So Breton's "breath of the street": the element that renders a thing both more startlingly present and plucked (or so it could seem) from the psychic Underworld. The American engineer-turned-photographer, Chauncey Hare, accepted a grant in the late 1960 s to knock on doors and walk into Midwestern homes to photograph how people lived, with an unannounced agenda of also photographing the owners. He froze the unsuspecting faces of these people with a wide-angle lens and a strobe light, and they end up looking like exhibits in their own homes-we could say "inhabitants," following Klein's notion of fake anthropology-in rocking chairs and lounging on couches. (Somehow, most of the people photographed believed they were out of the camera's range.) There is hardly an image in Interior America that doesn't look like it was staged by Buñuel. For those of us on a lower rung of achievement, photographs are ways to gather in what job promotions and house purchases cannot - the bright shards of Fuji graffiti we prop up on the piano, hang on the wall, magnetize to the refrigerator, set on the 
desktop, tape to the inside cover of a favorite book are totems and, maybe, advertisements. Pictures of gatherings, birthdays, weddings, picnics, vacations to exotic Toronto; for some of us who have been to school, the photograph is maybe also a way of writing a song: this is my wife, gardening; this is my trip to Nice, nice. My life, in medias res.

At their best, pictures are memory rods, routes to assemble our sense of our past, of believing in ourselves as real, inside the tide and wind of regular life. In family photo albums, pictures combine in group Bildungsromans. On the shelf, they say, Here is the sovereign self I've been telling you about. They say, Viewer, I grow. Why else take pictures? "The camera is the ideal arm of consciousness in its acquisitive mood," Sontag writes, floating the idea that taking images from the world is a listing toward barbarism. For the many of us, however, those Pluto moments feel real and to some extent promise to explain us, maybe even idealize us.

On the other hand the pictures we go back to look at again-the ones I do-are the ones that make a different sense than the one we thought we were making. They work like good poems: there is a something in them, a puzzle, that drives us back. A friend of mine who teaches Wordsworth visited Italy in his twenties and took a picture of a narrow street that tapers crookedly. He hung it in a hallway of his house, where it stayed into his forties, a framed haunting that said he was there, but because he was behind the camera he was also not there. It is a picture, hanging near his bathroom, of his own disappearance, or so my fancy leads me to believe.

The camera's history runs through chemistry and glass and pretty engines that combine the two to create images. Janet Malcolm writes in Diana and Nikon that photographs are basically paintings in their composition, in their sense of mythically ordered human space and time. That description tends to look even truer today with digital manipulation. Leonardo da Vinci invented the camera obscura-a box with a pinhole on one side that captured and projected light and images onto the back. A few years later, Johann Kepler gave the box its name, and in 1611 he laid down the laws by which single and compound lenses would project images, and explained why the image was reversed. These images would not become permanent until a French chemist named Joseph Niepce, working with a mediocre painter named Jacques Daguerre, accidentally fixed an 
image on plates coated with iodized silver in contact with mercury fumes (a jar accidentally left open all night). The first fuzzy photograph was made in 1826-a device for aiding artists, as the original camera obscura aided painters like Vermeer with their compositions. An Englishman named William Talbot discovered the reversed images we call "negatives" also by accident: his cat upset an extract of nutgalls on some half-exposed papers coated with silver chloride.

So accident is also part of the interior history of photography. And after Matthew Brady, who carried his darkroom with him to the Civil War, and George Eastman, who manufactured the first compact roll-film and called it "Kodak," possibly because the word was odd and because it sounded a little like the click of a shutter, the nerdy hobby we presently take as a national birthright grew. The machines made now are remarkable but they could just as easily be spray cans at the Roman Coliseum ("I was here") or at Black Angus ("I am a year older") —and as such they are unnatural manifestations of the liberal glorification of the subject, of me. If everyone is now entitled to an oral history for something or other, we are quickly arriving at the absurdist point that is nevertheless hard to deny, given national rhetoric, that all lives are glorious and original.

That they are not is unpleasant to recognize and not very middle class to allow. But running against that are the most interesting photos of the twentieth century which have been, with few exceptions, photos of outsiders, of strangers, of failures and the soon-tobe-deleted. The Kennedy clan, so photogenic, so easily connected to a line of, say, Egyptian sun gods, of Praxitilean destiny, exists mostly as home movies and some official White House shots of a president deep in thought. The more estimable work of photography has belonged to the soulful tradition of Dorothea Lange and Walker Evans, those Depression-era gatherers of faces and clapboard, grit and floorboard and misery who carried into the field an Aristotelian conviction that the accurate representation is itself pleasing. But they worked with large, heavy cameras, slow lenses and slow film. The life they captured was still and sculptural. If they somehow froze the running dogs of capitalism on their glass plates there were no actual dogs in their images, at least none that moved.

A decade after the Depression and World War II the photographic world was suddenly ajar with motion-granular, speed-happy, 
convulsively time-driven. Robert Frank's work-an Australian cinematographer told me recently that he found Frank "incomprehensible, like a miracle" - was probably unlikely without the on-the-road example of Lange and Walker. In 1954-55, around the same time that William Klein was shooting New Yorkers on Tri-X black-and-white film, and the same year the young Elvis Presley entered Sam Philips' Union Avenue studio, the Swiss-born photographer won a Guggenheim to drive across the US in search of lost America. Jack Kerouac wrote the introduction to this seminal book, titled The Americans, and he placed Frank "in a used car" not unlike the one Kerouac traveled in. Frank took pearly images of forlorn and forgotten people, often without perfect focus, and rapidly, and with a scandalous lack of applied method. Janet Malcolm described his technique this way in Diane and Nikon: "He scrupulously shed all the pictorial values of his predecessors-composition, design, tonal balance, print quality-and produced pictures that look as if a kid had taken them while eating a Popsicle and then had them developed and printed at the drugstore."

Frank used his camera as a fugitive tool, Sontag's "ideal arm of consciousness in its acquisitive mood," but without her sense of stony-eyed judgment. In arguably the most remarkable picture in The Americans there is also, above all, the accident of light - the deadly pallor cast by an overhead fluorescent light, of body language he could not have predicted or arranged. Titled simply Bar-Gallup, New Mexico, it is an image of the haphazard in a tilting frame. The picture holds the eye because we can imagine that the little cowboy standing there never knew, will possibly never know, that he has been captured, may not remember being in the bar or

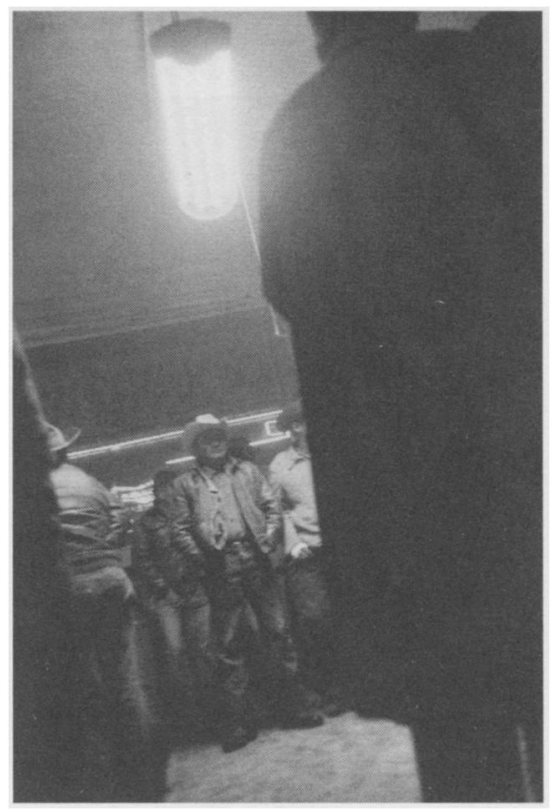




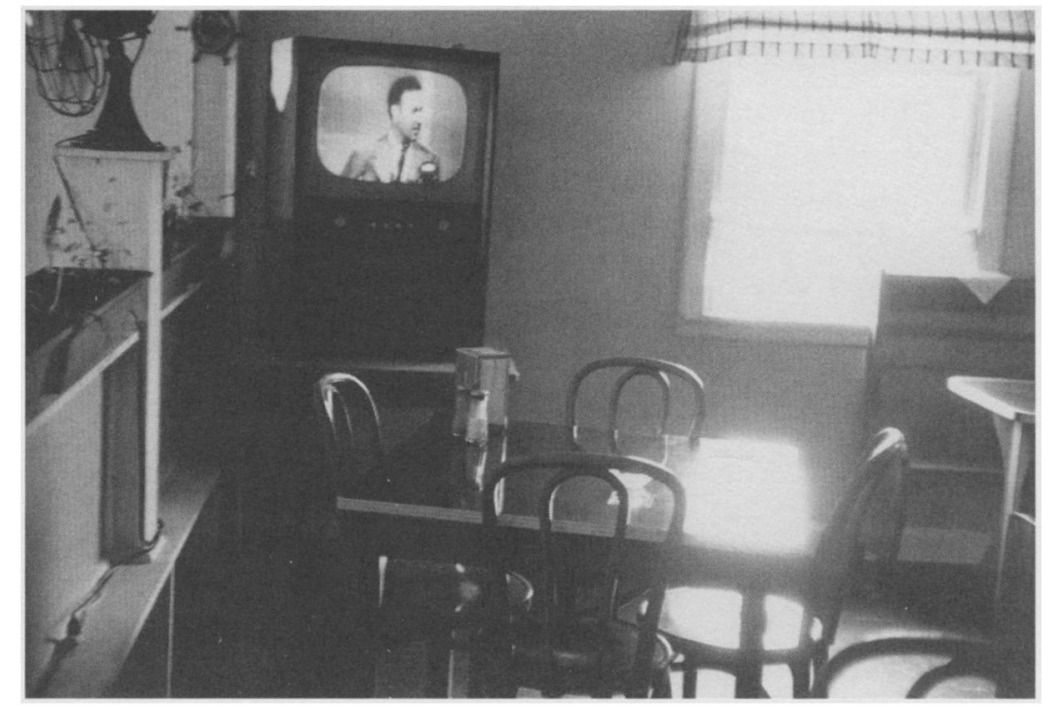

what he was thinking when he crossed Robert Frank's path. But more than the subject's disposition is the look of the picture: the darkness at its edges gives the picture a funny look: turn the picture on its side and it could be the light cracking into the opened lid of a coffin. Kerouac said the book gave Frank "rank among the tragic poets of the world." Kerouac is wrong about a lot of things, but he was all money when he wrote that.

When Frank photographs an empty table near an overexposed window, next to a TV turned on, he is saying something about the simple beneficence of light (like Vermeer) and the awful facticity of the human moment (like Vermeer). God is in Frank's details, too: there are numerous shots in The Americans of the various American signs of salvation-juke boxes, gas pump tomb stones, massive background light. Details in Vermeer could point to a Protestant world view in which an unstained window is the plain light of revelation. In Frank, light seeks no human figure but bursts hugely at the window and appears to say "life" against the frozen televised face of the man on the television. Were the figure on television a preacher, Frank would have managed to say something startling, deep, poignant and wholly irrational about America, religion, television, and emptiness-all at once, in a rush. (The photograph is titled Restaurant-US 1 leaving Columbia, South Carolina.) 
Dorothea Lange or Walker Evans made it their work to photograph people they had come to know, if in a brief time. Frank grabbed bits and pieces of the landscape, of personalities not blighted by an economy that had turned against them but by personality itself-by obsession, by the turmoil of dreams not achieved. So where Lange's people will look into the camera's lens, already knowing, and trusting, the woman who stands behind it, Frank gravitates to haphazard objects and to the improvisational act of swiping them from passing cars or trains, or from a car pulled over to the side of the road.

Sontag has little patience for these ontological pursuits. In On Photography, she argues that photographers like Arbus-and we can include Frank, Klein, Mann, Hare, Winogrand, and Merritt here-are exponents of "the Surrealist bluff," creating cheap imitations of dreamlife for the express purpose of upsetting middle class audiences.

But cheap imitation isn't Surrealism, which aimed at a better take on life. In A History of Private Life, Paul Veyne remarks of the portrait of a Pompeiian couple from the second century A.D., "this portrait, so like a snapshot, establishes their identity by depicting them ... these are not flesh and blood people caught at some arbitrary moment in their lives, but individualized types belonging to a society that conceived of itself as both natural and ideal."

Veyne is writing with the assumption that one of the possible purposes of higher art is to reveal the truth about individual lives, individual citizens. When I return to my snapshot from so long ago I can see that my brother is no longer quite my brother, my mother not really the woman in the window. The photograph has made them something else, not individuals but figures. Time has done that too, separate from the photograph, but in agreement with it. Yet they are people I recognize: they are not exactly "figures," not yet, but they are certainly not individualized in an ideal sense, and not in Veyne's sense. They are family but probably more so they are design: over time they are more interesting to me as a way to think about time. My brother, alive today with wife and children, is not even a little like the shut-eyed boy in the plaid car coat.

The culture of the century just finished, as many people have begun to see, is the century less of T.S. Eliot and Virginia Woolf than of Gertrude Stein and Marcel Duchamp; of Franz Kafka and Andy 
Warhol. Don DeLillo, a late- twentieth century master of transience, begins his slender novel, The Body Artist, with this paragraph:

Time seems to pass. The world happens, unrolling into moments, and you stop to glance at a spider pressed to its web. There is a quickness of light and a sense of things outlined precisely and streaks of running luster on the bay. You know more surely who you are on a strong bright day after a storm when the smallest falling leaf is stabbed with self-awareness. The wind makes a sound in the pines and the world comes into being, irreversibly, and the spider rides the wind-swayed web.

DeLillo may be the most lyrical observer of the "moment" we have right now. He acknowledges the Zen whirl of the plain world, holds it up to his eye until the surface offers up its own shape to himand its own voice. The spider web, his figure for "things outlined precisely," is also the hinge for a world of sunlit blur: the "windswayed web" is the fatal chain link over the world that so appalled Robert Frost in "Design." But for DeLillo the web's design is slight, a tidy corner of precision in a day big enough to tear it away.

And: "Time seems to pass." With its tide-pull irony, the sentence stands in the same relation to flux as photography does. A Surrealist bluff? Henri Cartier-Bresson, widely regarded as the finest photographer of streets and people in the western world, was impressed as a young man by the French Surrealists, the Symbolist poets, and by Freud's work on dreams.

The twentieth century, George Steiner observed in his most recent work, occurred under the sign of Dada, Tristan Tzara's movement of rage against the demise of rationalism as evidenced by the trench warfare of World War I. Lest that seem extreme, lest the notion that Marcel Duchamp is mental king of the last hundred years bring fear to your heart, remember that the central high-water texts of the century-Ulysses, The Waste Land, The Cantos, The Autobiography of Alice B. Toklas, The Interpretation of Dreams, The Trial, To the Lighthouse, Godard's Weekend-are all built around forgotten, or nearly forgotten, fragments, Percy Bysshe Shelley's hollow sense in "Ozymandias" that the mighty and the grand in the modern age are negligible and fading. 
Photography as I've been describing it is not just the aggressively strip-mined "real" that Sontag shakes her head at, and which she regards as the cynical work of fakers too lazy to make good sense. It owes something to the irrational-to the favor of chance and fortune. As such it will upset a rationalist with its weird intuition that accident improves art. It's what John Ashbery means, I think, when he writes in Flow Chart about the frame:

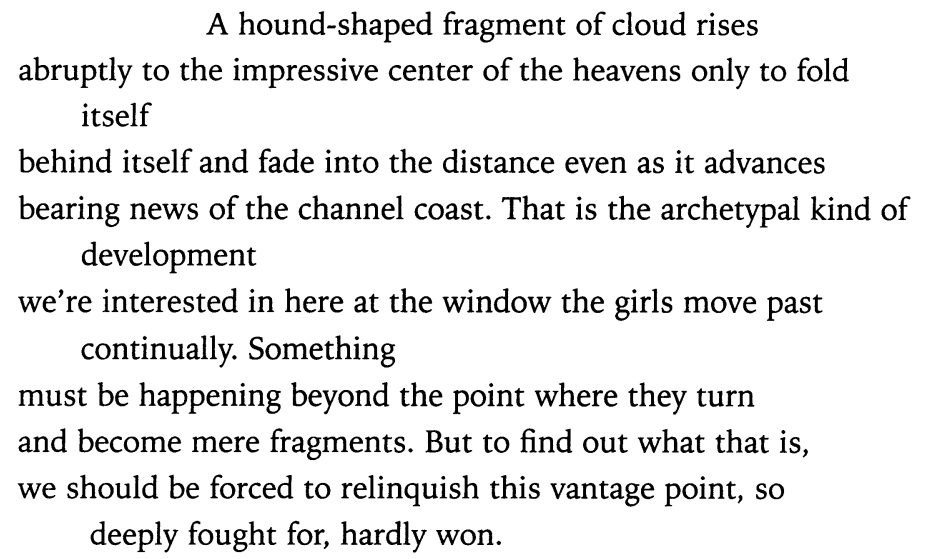

The window Ashbery writes about is comparable to the photographer's frame, where the world beyond it may as well be bursting into "fragments," like the girls. Ashbery worries about relinquishing the "vantage point, so / deeply fought for, hardly won" but his writing has always suggested that that's where the fun is. The promise photography makes in electing its multiple temporary portals of entry into the world is the promise of the discovery of the fragments outside the window.

My photograph, once more. I have a strong memory, not captured on film, of my mother coming out of the house shortly after the picture is snapped and yelling hard at me as my brother was about to snap my picture, mid-chin-up-something about my thirteen-year-old's weight pulling down the awning and fucking up the whole house. 